\title{
Rape, sexual politics and the construction of manhood among the Shona of Zimbabwe: Some philosophical reflections
}

\author{
Pascah Mungwini \\ Department of Philosophy \\ National University of Lesotho, Lesotho \\ pmungwini@yahoo.com
}

\author{
AND \\ Kudzai Matereke \\ School of History and Philosophy \\ University of New South Wales, Australia \\ kudzaimatereke@yahoo.co.uk
}
Thought and Practice: A Journal of the Philosophical Association of Kenya (PAK) New Series, Vol.2 No.1, June 2010, pp.1-19 thoughtandpractice@gmail.com OR thoughtandpractice@uonbi.ac.ke http://ajol.info/index.php/tp/index

\begin{abstract}
This paper interrogates the language that mediates sex and sexuality among the Shona of Zimbabwe. It draws from the method of ordinary language philosophy to argue that culture, and specifically language, can constitute an effective incubator for the emotions that result in rape. Further, the paper shows how the constructions of masculinity among the Shona render the female body a subject of male dominance. The paper contends that culture, through the stories that it tells about sex and the
\end{abstract}


language it uses to tell them, has a strong potential to initiate and sustain emotions and behavior that lead to rape. However, this predatory behaviour can be struggled against and contested by revisiting the language that society uses in the important domain of sex.

\section{Introduction}

...while the assembly of facts and collection of statistical data may be an important part of practical problem-solving, they cannot in themselves always provide the answers we need. Solutions to the problems of political and social life must in the end be sought in the kind of reflective consideration characteristic of an outward facing philosophy (Almond and Hill, 1991, 6)

For quite some time public media have carried unsettling stories of rape, ranging from the rape of minors, the elderly, people with mental disabilities, and women in general. Court cases are heard, people are incarcerated, shocking statistics released, campaigns against sexual abuse and rape held, but each day brings with it even more horrendous cases of sexual violations such as gang rapes and the rape of infants. Despite the potential dangers of disease infection and the heavy penalties imposed on rapists, rapists are not deterred. Yet there is an uncomfortable nexus between rape and citizenship, as rape has a significant impact on belonging and participation in the polity. Women shun public space, and their identification with public institutions is compromised, because of the fear of being raped or assaulted.

This paper undertakes an analysis of the problem of rape within the cultural context of the Shona people of Zimbabwe. The paper argues that there are linguistic roots to the problem of rape, hence the need for a philosophical interrogation of the language that mediates sex and sexuality among the Shona. The paper contends that culture, through the narratives it tells about sex and sexuality and the language it uses to tell them, has a high potential to initiate and sustain emotions and behavior that lead to rape. Oduor (2009) rightfully points out that there are a variety of impediments to desirable social transformation in contemporary Africa. Among them are culturally sanctioned forms of thinking and practices that promote the subjugation and exploitation of women. This work examines one such toxic element in our culture, that is, the problem of rape. 
As Gyekye (1997, 27) notes, in times of wonder, confusion, instability and uncertainty, in times when the definition and articulation of values become more urgent, in times when the search for fundamental principles of human activity becomes most pressing, in such times, the services of the intellectual enterprise called philosophy becomes indispensable. In his forceful argument for the relevance of the philosophical enterprise to human affairs, Gyekye states that philosophy "is essentially a critical and systematic inquiry into the fundamental ideas or principles underlying human thought, conduct and experience" (Gyekye 1997, 5).

Rape constitutes a complex problem for a number of reasons. First, as regards the very concept itself, literature that confirms rape as a controversial term abound (e.g. Scully 1994, Smith 2004 and Rowland 2004). Second, it is generally accepted that rape is an underestimated problem because it is underreported, and also that there is a strong tendency to blame the victim (Groth and Birnbaum 2004, Miller 2004, Estrich 1987, and Rowland 2004). Third, the problem of rape is made more complex by the myths that are embedded in its analyses (Ward 1995, Benedict 1993). Fourth, it is an established fact that despite the acknowledgement of the prevalence of rape, little is being done to make public space safer for women. The debates on rape are masked by what du Toit $(2005,256)$ calls "the institutional 'normalisation' of rape whereby rape is officially illegal but officially tolerated". Thus rape is a complex phenomenon with far-reaching implications for social well being in general.

In her recent publication, A Philosophical Investigation of Rape: the Making and Unmaking of the Feminine Self (2009), Louise du Toit offers a critical feminist perspective that highlights how rape intersects with the issue of feminine subjectivity, and how phenomenology can be brought to bear on understanding rape. The discourses on rape have prompted philosophers to re-examine the nexus between culture, embodiment, knowledge of the self and the creation of subjectivity. Rape is a phenomenon that takes place on the body, but it has strong ramifications on the mind. Rape is experienced by women who desire to 'fully own' their bodies. The notions of the body are grounded in culture and expressed in language. 
The present paper interrogates the way in which the concept of rape is understood and talked about among the Shona of Zimbabwe. Chiroro et. Al. $(2002,2004)$ have shown how rape constitutes a major form of sexual abuse among women not only in Zimbabwe, but the world over. Pressure groups working in tandem with international organizations have also advocated for awareness creation and decisive legislative reforms to deal with the phenomenon of rape. However, whereas other works have dealt with 'rape' as a social phenomenon, our analysis seeks to deal with it as a phenomenon that intersects with other interests such as morality, feminism, and, most significantly, language.

\section{Theoretical Framework}

The reflections undertaken here are informed, among other things, by the distinction between 'necessary' and 'perverse' questions in African philosophy (Vest 2009). Vest urges African philosophers to shift from perverse questions and embark on necessary ones. She contends that the shift can start 'once we ask new questions, and also answer old questions in new ways and make important metaphilosophical contributions (Vest 2009, 3). The discourses on rape in Africa have not dealt with the issue from a metaphilosophical perspective. Consequently, we show how the Shona conception of rape is embedded in the linguistic and social configurations of this community. In this vein, we consider ordinary language philosophy as a metaphilosophical endeavor to establish the place of language in the way humans make sense of the world. The motivation behind this approach is the realization that concepts must first and foremost be cultural and local before they can become universal.

This work is situated within the discourse of philosophy of culture, and draws from the method of ordinary language philosophy to examine the extent to which culture, and specifically language, can constitute an effective incubator for rape. Ordinary language philosophy can enable us to explore the specific context in which thought, utterance and action take place. The understanding is that language when subjected to description and analysis can yield novel and coherent philosophical insights. Ordinary language philosophy is here simply taken as the exploration of language to understand the epistemological, metaphysical, ethical, social and political beliefs of a particular 
society (Fasiku 2008). The paper draws from the abundance of figurative language relating to sexuality among the Shona to argue for the need to revisit some aspects of this language that have constricted the space for women by fomenting sexual aggression, thereby stunting desirable social transformation. The attempt to locate the philosophical discussion of the phenomenon of rape within a specific cultural setting is in part motivated by the desire to make philosophy play its role in the collaborative endeavour to understand and improve the world.

Examining language as used and understood within a specific culture also implies contextualism - a theoretical framework that can be applied to a broad array of fields of investigation including culture, religion, morality and epistemology. Hanson (1979) applied it to religious and cultural discourse to circumvent the limits of both objectivism and relativism. In epistemology, Annis $(1982,51)$ used it to argue that certain social and cultural features are essential to any adequate theory of epistemic justification. Thus contextualism rejects the claims of universalism, and argues that humans are agents who employ their unique circumstances to make sense and act in the world, and that they are agents whose function can only be fully understood within their cultural context. Thus cultures "have created different epistemologies to understand, predict, and manage their environment" and "these organized bodies of knowledge provide meaning, direction and coherence” (Kim et. al. 2000, 69).

In analyzing the language that arouses the sexual emotions that trigger rape, this work also adopts the social constructionist approach which views emotion as created and understood in the context of relationships with others and made meaningful through discourses, language and signifiers. As Boellstorf and Lindquist (2004) have noted, feelings are not substances to be discovered in our blood, but social practices organized by the stories that we both enact and tell. It is for this reason that if the Shona are to transform the feelings of sexual aggression that lie at the root of rape, they need to change the stories they tell about sex, their conceptions of sex, their perception of women and the whole gamut of linguistic expressions that portray women as objects to be enjoyed rather than equal partners with men in sexual activity.

The Shona have been selected for analysis in this work for the simple reason that they are the community that the writers are most familiar with. The group of people called 
the Shona speak one or other of the dialects of what the linguists call the Shona cluster of languages (Gelfand 1973). This group of people constitutes more than three quarters of Zimbabwe's population.

\section{The Concept of 'Rape'}

In his philosophical investigation of rape and the law, Burgess-Jackson (1996, 3) states that his philosophical aim "is to sift and sort through the various issues that arise in the law of rape, distinguishing those that are conceptual in nature from those that are normative or empirical, and showing how, where, and why these issues are interconnected." In line with his analysis, we seek to make philosophy relevant to the discourse of rape. The history of the development of philosophy indicates that one of the major aims of philosophy is conceptual clarification. Bishop (1992) argues that the trademark of (Western) philosophy is the attempt to analyze concepts. Analysis, according to Hirst and White $(1998,2)$, is "the elucidation of the meaning of any concept, idea or unit of thought that we employ in seeking to understand ourselves and our world, by reducing it, breaking it down, into more basic concepts that constitute it and thereby showing its relationship to a network of other concepts or discovering what the concept denotes." This understanding of analysis highlights the fact that concepts exist within a web of relations with other concepts, hence the need to explicate, draw boundaries and establish connections between them.

The meaning of the term rape has continued to shift over the years, as new sexual encounters that were initially regarded as normal, and therefore acceptable, come to be classified as rape. This is due to the development of new insights into issues of gender and sexuality, as well as the enactment of new laws that continue to broaden the horizon of the concept. Credit must be given to those scholars who have championed gender research, and to feminists who have challenged the patriarchal conceptions of sex and gender, thereby enlarging the cultural window through which societies can look at the world and make sense of it. What is more, the movement of women from the periphery to the centre of social discourse has enabled them, through their experiences that were previously taken as private, emotional and irrational, to make a significant contribution to various aspects of society. This movement from the periphery is what Spivak (1988) calls the rise of the 'subaltern voice'. 
While issues of gender and women's rights have only recently been brought to the fore in much of post-colonial Africa, they have already had a significant impact on the continent's societies. Like a living organism that continues to grow and therefore change, the logical geography of rape has continued to shift as cultures come into closer contact with each other, and as more and previously neglected research makes its contribution to gender epistemology. Of particular interest is the understanding of rape which extends the meaning of the concept to describe some sexual encounters between legally married couples, as well as in the whole domain of what was traditionally accepted such as forcibly sleeping with the younger sister to one's wife. An examination of rape within the context of culture is important, as culture constitutes the living philosophy that houses the value system which regulates social space and conduct between individuals within a society.

The Shona equivalence for the word rape is kubhinya or the phrase kubata chibharo. Literally the term 'kubhinya' means to waylay someone in order to forcibly have sex with them. A person referred to as a binya is someone who is ruthless and has no regard for life, and for that reason the term binya is also often used to refer to a murderer. The term kubata chibaro, on the other hand, originates from the colonial practice of rounding up all able bodied men in the reserves and forcing them to work in mines, roads and railway construction, or in any other labour intensive project for very little or no pay. These two terms highlight the use of force against a woman. The words capture the dehumanizing nature of rape. Among the Shona, rape is an emotionally charged concept and has a bearing on one's personhood. The term arouses emotions of anger and outrage, and when one is defined as a rapist (bhinya) there is no doubt that the individual in question is dangerous to the entire community and has lost his sense of personhood.

Among the Shona, the classical understanding of rape is forced sexual intercourse with a man who does not love the woman he sleeps with, or a man who is a total stranger, who violently engages in sexual intercourse with a woman, a child or with a person with a mental disability who is incapable of understanding sex. The sexual encounter is associated with the use or threat of force. It is for this reason that the word chibharo, which also means forced labor, has been used to describe rape. The 
word also suggests the female's supposed response to the male predator. The general expectation is that a rape victim will scream and fight back, and where a woman has been raped she will be bruised all over her body, with her clothes torn apart. The rapist is also expected to bear the marks of the struggle such as scratches and bites from his victim. This is transgressive rape, which is in direct contravention of the social norms regulating sex. However, it is when what traditionally constituted normative rape is redefined to fall under transgressive rape that much debate arises, because the re-definition interferes significantly with culturally acceptable behaviour associated with the expression of manhood in sexual relations.

The analysis above indicates that rape is a violent act that threatens the very being of the victim. There are clear links between rape and the HIV/AIDS pandemic. The links are essential in several ways. First, rape is associated with the spread of infection. Second, rape has also reached epidemic levels just like the HIV/AIDS pandemic. Third, rape results in traumatic experiences that warrant it being called 'a death sentence'. Thus following du Toit's employment of the Derridean approach, it can be argued that rape is a death sentence and therefore a capital crime because "it murders the subject-self of the person against whom the crime is committed" (du Toit 2007, 198). Burgess and Holmstrom (1974), in their analysis of the rape trauma syndrome, characterized rape as an act of violence which uses sex as a weapon. As will be highlighted below, the construction of Shona masculinity presents the male in contraposition to the female, thus attributing the active role to the male and the passive role to the female. Patriarchy stresses that power lies in the males who oversee, control and discipline women and children. In this light, sex is used as a disciplinary act to which women must be subjected if they do not conform to expectations.

\section{Relocating the Body in the Discourse on Rape among the Shona}

Foucault's Discipline and Punish (1977) has revolutionized debate on the body by highlighting how the body is produced in discourse as it responds and resists various discursive formations. Feminist discourses have used Foucault to explain the ways in which patriarchy as a system exercises power and control over women. Thus in the Foucauldian formulation, the body is the object to which the microphysics of power is 
applied to produce 'governmentality'. It needs to be emphasized, however, that not all feminists are satisfied with Foucault's account. For example, Cahill (2000, 43-44) accuses Foucault of decriminalizing rape by choosing to define it merely as an act of violence but not as a sexual crime, thus making rape just like any other form of assault. Despite this criticism, Foucault's analysis of the body can provide insights for our present purposes. According to Foucault (1977, 153), the body is "totally imprinted by history" and:

is broken down by a great many distinct regimes; it is broken down by rhythms of work, rest and holidays; it is poisoned by food and values, through eating habits or moral laws; it constructs resistances (Foucault 1977, 153).

The Shona society operates by designating and differentiating space and assigning it to specific gender categories. The consigning of bodies to specific spaces ensures that they occupy and co-opt space through action, so that they realize their agency. The separation of spaces into private and public, and the allocation of bodies to the specific space is also a way of investing power in the body. Ideas such as 'decency', 'beauty' and 'culture' are at the core of this investment of power in the body. Within this framework, bodies partake in routines to perform tasks and roles. The Foucauldian model of analyzing the body significantly highlights how the body should be viewed as a text on which power and knowledge are inscribed. Emphasis on decency, deportment, presence and absence from space and the offer of reward and punishment are evidence of the ways the body is a social construct and a means of self expression or performance by which identity and value are created, tested, and validated (Dutton 1995, 13).

Foucault's analysis of institutions emphasizes how the notion of 'the gaze' is important for controlling behavior and for self-discipline. Prisoners, mental health patients, factory workers and the military officers 'appropriately' behave because of the real or imagined gaze of the supervisor. Thus the gaze is productive: it produces the identity of those whose bodies are subjected to the surveillance process. By the same token, the male gaze controls the behavior of the Shona women as it modifies the ways they carry themselves, and prohibits them from occupying some spaces. The Shona females are taught to kneel before elders (especially men), to sit with legs crossed, and to dress appropriately to cover specific parts of the body. It is within this 
context of cultural expectations that rape and the narratives of its victims are usually explained away: for example, that it is a woman who provokes a man; or that the woman was not supposed to have been in that place in the first place; or that any normal man could not have behaved any different. Moffett $(2006,132)$ calls these explanations 'justificatory narratives' or 'narratives of normalisation' which seek to legitimize the violence of the dominant against those who are disenfranchised.

The Shona, like any other patriarchal society, can be viewed in a similar vein. The males as heads of the families play the role of 'protecting' and 'supervising' the family units. They exercise their power by employing the gaze, and use the socialization processes to enhance male dominance and retain the females in subservient positions. The insistence on the 'male gaze' to which women have to respond by modifying their behavior 'appropriately' or risk the consequences (including rape and other forms of assault) highlights how women are constantly in danger, and how men are easily exonerated. Commenting on the strength of the gaze, MacCannell and MacCannell wrote:

[It] does not have power in itself but only in association with actual violence or identification with those capable of violence.... Everyday experience structurally and psychoanalytically binds power and the gaze. Power and the gaze are always linked in the mind of the intimidated (MacCannell and MacCannell 1993, 215).

The power that men enjoy is embedded in the ways the body and its parts are constantly defined. Thus the man as the head of the household wields power because he carries with him the 'seed' of the clan. Phallic power is therefore celebrated, and the female is expected to curve her niche by serving the man's phallocentric desires. As Haber $(1996,138)$ observes, a woman's body and its parts are "judged from the standpoint of male desire".

To appreciate the extent to which the phallus wields power among the Shona, it is helpful to consider how male sexual organs are described in disciplinary terms. Patriarchal Shona men usually describe vocal women who stand up for the rights of women as morally loose. The usual question is: "mukati ane murume iyeyu?" [by the way, is she married?] Thus marriage is conceived as a way of social control. If it is confirmed that she is married, there is usually a condescending response that the 
husband is weak and has failed to discipline his wife. The weakness alluded to here is at two levels. First, the husband is perceived to have physical weakness, in that he has failed to use persuasion, violence or the threat of it, to control his wife. Second, the husband's perceived weakness is in terms of his sexual potency, since it is believed that women who become active in the public sphere are those who do not get satisfaction in their sexual lives, so that the public sphere is a relief for their unfulfilled sexual appetites or is a place where they can get men to 'quench their thirst'.

Among the Shona therefore, the phallus is described as a disciplinary object for women, thus the usual metaphor of the phallus as a whip which instills discipline. When young men boast about the size of their sexual organs, they are thinking of their future roles as 'disciplinarians' or 'pacifiers' of the females, whose bodies are depicted as exotic, wild, insatiable and deviant. It should be emphasized that it is also common to see the female body depicted as the pacifier of the male ego, thus tilting power in women's favor. Either way, the central role of the phallus is confirmed.

$\mathrm{Du}$ Toit $(2005,253)$ contends that "sexuality and the ways in which it is played are political issues." This is one of the key aspects of feminist theory. Bourque (1990) noted:

As applied to rape, feminist theory is essentially a theory of stratification, social control, and implied social conflict. Its major tenet is that power is unequally distributed by sex: Men have power; women do not. Power is inherent in being male and is enhanced by physical attributes and control over access to education, job, and money...Society portrays women as passive, expressive, emotional, characteristics that are viewed negatively. Men are portrayed as aggressive, dominant, and virile, characteristics that are viewed positively (Bourque 1990, 14)

From the preceding discussion, it is clear that rape should be viewed within the context of the ways in which men have conceptualized the female body. Thus Cahill (2001, 78) characterized the body as an expression not of individual, internal dynamics, but of the dominant social discourses that surround the subject, as well as a network of complex and interlocking relationships and dynamics. Patriarchy accords the man a higher position than the woman by defining his body as more powerful than her's, and by depicting her body in negative terms. 


\section{Unmasking the Cultural and Linguistic Incubators of Rape}

Simply defined, sexism is an outlook which exploits the female person by the way it characterizes and marks the distinctions between males and females. In highlighting how sexism manifests, we follow Glick and Fiske's distinction between hostile and benevolent sexism. While we cannot exhaust Glick and Fiske's analysis of these concepts here, sexism of either type views women stereotypically, and seeks to keep them in a subject position, sustaining the view of "the man as the provider and the woman as his dependent" (Glick and Fiske 1996, 492). In this regard, it is important to reflect on the role that the Shona culture, and specifically the Shona language, plays in nurturing an environment conducive to the perpetuation of the rape of women.

Among the Shona, the subject of sex is shrouded in secrecy. It is taboo for anyone to pontificate on issues of sex. Consequently, there are people who are regarded as the only ones capable of addressing the issues of sex depending on the nature of the relationship between the teacher and those who are taught. Culturally, parents are not at liberty to discuss issues of sex with their own children. Instead, people regarded as appropriate such as aunts and uncles are supposed to take a lead in talking to the young of their own lineage in this area. However, the unfortunate development is that with the advent of modernity and especially urbanization, it has become very difficult for families to remain closely knit enough to allow the aunts and uncles to play this role. Even the combating of HIV and AIDS through sex education has been extremely difficult because very little is openly taught about sex and sexual encounters between boys and girls. Thus the domain of sex has remained a haven for all sorts of ideas, fantasies, myths and mysteries that nourish emotions of rape.

A closer look at language reveals an important source of sexual aggression and rape among the Shona. The language of sex, which is a special kind of discourse, comprises both formal and informal terms that indicate the salience of male dominance and aggression. A quick selection of the language of sex and even courtship reveals how women are reduced to passive recipients, while men are regarded as the active agents in matters of sex. For example, starting at the very act of proposing, it is culturally expected that men propose while women are proposed to. In 
Shona this is the clear distinction between kunyenga (to propose) and kunyengwa (to be proposed to). As Chimhundu $(1995,149)$ notes, the Shona language has built-in sex differentials, and the transitive verbs that indicate courting, marrying or making love can only be performed by male subjects, and those that refer to women present them in object positions. Chimhundu's observation highlights the fact that rather than women acting, they are acted upon, so that their agency is rendered insignificant.

Thus among the Shona, the body is a gendered category, as certain essentialist qualities are attached to it on the basis of the particular parts that it possesses and are assumed to bear on their owners. This has also been observed elsewhere, where many of the words used by males to refer to females are not only laden with pejorative attitudes, but also contain nuances that are encrypted in connotations which discriminate against women, thus confirming that language reflects and reinforces existing social structures which are to the disadvantage of women (Githinji 2008, 29). Further, courtship language is usually metaphorical in nature, reinforcing not only the passivity of the female folk, but also their objectification. For example, the Shona word kuruma (to bite or sting) referring to courtship, carries the connotation of men as invincible and irresistibly witty. Nevertheless, this is not to say that Shona women do not resist any advances that men make, but it suggests that the expectation that men are dominant and women are passive breeds an aggressive masculinity.

The Shona are a totemic society. Such a society venerates plants, animals or animal body parts as symbols of specific clans. The sexual behavior and qualities of the animal (totem) are readily appropriated to the clan members. The physical characteristics of the totem are easily accorded sexual connotations, with emphasis on such qualities as virility, potency, wit and agility. The sexual behavior of an individual can therefore be explained and justified merely by an appeal to his totem. In other words, totemism among the Shona has contributed to sexual perversion, serving as a vehicle for the "institutional 'normalization' of rape" (du Toit 2005, 256), as rape can be explained as a normal manifestation of a man acting in consonance with his identity as defined by his culture.

Among the Shona, there are cultural expectations that girls and women will resist any sexual advances from their male counterparts in order to prove that they are not 
sexually weak and promiscuous. It is for this reason that when a boy makes sexual advances to his girlfriend, he does not take seriously her attempts to say "no" because he anticipates them anyway, and this adds to his aggression. Commenting on these expectations in Zimbabwe, Musarurwa wrote:

A woman has to struggle as a matter of duty and honour to defend her chastity. There is also the feeling that if she quickly and cheaply gives in her man will think she is a cheap woman who will sleep with anybody on request. Men are always faced with the problem to determine the amount of force they have to use. If it is too much it becomes rape. If it is too little it achieves nothing. They are in a dilemma. The mid-point is very elusive (Musarurwa 1988).

The belief that success in getting a girl to bed depends in part on the amount of force that a man uses relative to her's indicates that sexual aggression is culturally sanctioned. This kind of aggression is also reflected in the figurative language that Shona men use to recount their sexual exploits to their peers. Below are a few examples:

Ndalaza - this is a Shona slang for 'I have eaten the 'thing'.

Ndadya zvinhu - I ate the things.

Ndachitsika - I have crushed her.

Ndachirikita - I severely thrashed her.

Ndachidhonora - I gave her a bitter thrashing.

Ndachibvumburudza - I wrestled her mercilessly and tore her to pieces

(this is consistent with the depiction of the male as the predator/hunter who pounces on the prey).

It is noteworthy that chi- (it) as used in several of the examples above is a subject prefix which refers to the female, caricaturing her as an object of sex.

Of particular interest are the last three expressions above (ndachirikita, ndachidhonora and ndachibhumburudza), that are extrapolated from their usual usage relating to the severity of beating or punishment that can be meted out on a wrongdoer. In the context of sex, the two expressions kudhonora and kurikita paint a picture of a hapless female who has been subdued by the man and taken through the whole sexual ordeal like some kind of sex slave. The whole act is true punishment which the man enjoys to administer. The male organ is figuratively portrayed as a sjambok (whip) used to mete out deserved punishment on the female. The last of the three terms above captures a situation that is characterized by severe struggle typical of a wrestling match that culminates in the woman or girl submitting or lying helplessly. It is from such kind of language that one can discern the roots of rape. The 
crying and groaning of a woman from pain is taken to signify male superiority, and is consistent with the idea of 'thrashing' and submission.

Thus the kind of language captured above demonstrates the extent to which sexual encounter among the Shona is couched in the language of aggression, brutality and conquest. As Chimhundu (1995) correctly noted, among the Shona sexual relations involve victory and conquest on the part of the male, and defeat and surrender on the part of the female. The orientation one gets as an adolescent in talking to one's peers about the subject of sex is one where the male figure has to be merciless when it comes to sexual encounter.

Among Shona men, both thinking of and planning for sex are associated with aggression and the desire to subdue, and these feelings are culturally sanctioned by the kind of language the men use to describe sexual encounters. Emotions are culturally constructed and do not exist outside language. They emanate from the language we use and the world it constructs for us. The point is that the discourse chosen by the Shona to capture sexual encounters is itself an incubator for sexual aggression. It promotes and instigates rape. The language of war can itself not be used to reestablish peace in a community, hence the need for society to develop an appropriate language for talking about sex.

Besides the figurative language used to describe the sexual act among the Shona, there are numerous other commonly used sayings that tip the scales in sexual relationships in favor of men. Even figurative language that purports to capture the value of women and particularly the female organ paradoxically turns out to be the very language that props up sexual aggression and eventually rape. For example, among other seductive metaphors, the female organ is referred to as dende rehuchi (a calabash of honey). This explains why some men literally salivate when they look at an attractive woman. It also partly accounts for the harassment of women clad in miniskirts, a common practice in urban bus termini.

Thus the woman is portrayed as having a calabash of honey which she keeps with her, and only occasionally issues to men to enjoy. It is noteworthy that honey is not easy to obtain from the beehive. While ingenuity is required to get it from there, it is also 
usual for those who harvest honey to burn the colony of bees if they prove too stubborn. Similarly, a female who refuses to let men 'taste' can be subdued, hence the problem of rape. Because the female organ is culturally portrayed as a delicacy just like honey, it heightens men's drive for it, and one cannot rule out rape for those who cannot properly negotiate for sex. Indeed, many a man has been reported to have told a woman that he would not mind going to jail because of rape, as he was dying to 'have a taste' of her!

The portrayal of female bodies as commodities to be enjoyed or feasted on by men is common in Shona culture. Even in circumstances where women are supposed to be in charge, the women themselves describe the whole sexual activity in a language that renders them more vulnerable. Phrases such as ndamupa (I gave him) and ndamuravidza (I allowed him to taste) portray men as negotiators, ultimate winners and enjoyers in this whole game, while presenting women as gaining nothing in the process. This is despite the fact that biologically, sexual pleasure is a balanced equation which some even tip in favor of women.

While it may sound like blaming the victim, it is a fact that armed with their numerical advantage and the support of male feminists, women have what it takes to bring about positive change to the language that society uses in the domain of sex, thereby serving as incubators for a new sexual culture in which both men and women are benefactors. The moment men feel used the conqueror motif dwindles, and this can have a positive effect on the incidence of rape. The social progress recorded in postcolonial Africa by most women has constituted a significant threat to the balance of power not only in the family, but also in our patriarchal society as a whole. Deterrent punishment of rape as directed by the law needs to be backed by linguistic reforms that smother predatory sexual behaviour among the men. Rape is a threat to all women, embedded and sustained by the unequal distribution of power and the masculinization of space. Describing his socialization into manhood within the Shona culture, Shire $(1994,147)$ recalls that the construction of manhood through masculinity was often shaped through the use of metaphors and proverbs, whose meanings he began to understand as part of the process of achieving linguistic competence as a man. This is the image of the 'real man' that must be urgently deconstructed. 


\section{Conclusion}

In this paper, we have offered a philosophical examination of the problem of rape, with specific reference to its manifestation among the Shona of Zimbabwe. Drawing from the works of eminent scholars such as Foucault and Du Toit, we have contended that the nexus between the body, self-knowledge, subjectivity and culture requires an incisive philosophical interrogation. As Gaidzanwa (1999) pointed out, images in society are socially constructed, continually reconstructed, struggled against, reinforced and renegotiated. This is true of the images relating to sexual relations among the Shona.

The central argument of the paper has been that culture, through the stories that it tells about sex and the language it uses to tell them, has a strong bearing on emotions and behavior that lead to rape. Consequently, the struggle against rape has to be broadened to include not only relevant pieces of legislation, but also efforts to get rid of the aggressive idioms used to package sex and sexual roles in contemporary African societies. Ordinary language philosophy can play a pivotal role in this endeavour, as it contributes to the fulfilment of philosophy's obligation to provide a diagnosis of society, thereby serving as a catalyst for social transformation in the interest of the oppressed.

\section{References}

Almond, B. andJ. Hill. 1991. Applied Philosophy: Morals and Metaphysics in Contemporary Debate. London: Routledge.

Annis, D.B. 1982. "The Social and Cultural Component of Epistemic Justification: A Reply". Philosophia, Vol.12 Nos.1-2, pp.51-55.

Armstrong, A. 1990. "Women and Rape in Zimbabwe", Human and People's Rights Project. Monograph No.10, Institute of Southern African Studies (ISAS), National University of Lesotho.

Benedict, H. 1993. Virgin or Vamp: How the Press Covers Sex Crimes. Oxford: Oxford University Press.

Bishop, M.A. 1992. "The Possibility of Conceptual Clarity in Philosophy". American Philosophical Quarterly, Vol.29 No.3, pp.267-277.

Boellstorff, T. and J. Lindiquist. 2004. "Bodies of Emotion: Rethinking Culture and Emotion through South-East Asia". Ethnos, Vol.69 No.4, pp.437-444.

Bourque, L.B. 1989. Defining Rape. California: Duke University Press. 
Burgess, A.W. and L.L. Holmstrom. 1974. "Rape Trauma Syndrome". The American Journal of Psychiatry, Vol.131 No.9, pp.981-986.

Burgess-Jackson, K. 1996. Rape: A philosophical investigation. Brookfield: Dartmouth Publishing.

Cahill, A.J. 2000. "Foucault, Rape, and the Construction of the Feminine Body". Hypatia, Vol.15 No.1, pp.43-63.

--. 2001. Rethinking Rape. New York: Cornell University Press.

Chimhundu, H. 1995. "Sexuality and Socialisation in Shona Praises". Furniss, G. and L. Gunner eds. Power, Marginality and African Oral Literature. Cambridge: Cambridge University Press, pp147-161.

Chiroro, P., A. Frodi and A. Tsigah. 2002. "Sexual abuse among Zimbabwean females: Nature, prevalence and victim-perpetrator relationships". Unpublished manuscript, University of Pretoria, South Africa.

Chiroro, P., G. Bohner, G.T. Viki and C.I. Jarvis. 2004. "Rape myth acceptance and rape proclivity: Expected dominance versus expected arousal as mediators in acquaintance rape situations". Journal of Interpersonal Violence, Vol.19 pp.116.

Chiroro, P., G.T. Viki And D. Abrams. 2006. "Hostile sexism, type of rape, and selfreported rape proclivity within a sample of Zimbabwean males". Violence Against Women, Vol.12, No.8, pp.789-800.

$\mathrm{Du}$ Toit, H.L. 2005. "A phenomenology of rape: forging a new vocabulary for action". Gouws, A. ed. (Un)thinking Citizenship: Feminist Debates in Contemporary South Africa. Aldershot: Ashgate, pp.253-274.

--. 2007. "Feminism and the ethics of reconciliation". Veitch, S. ed. Law and the Politics of Reconciliation. Aldershot: Ashgate, pp.185-214.

--. 2009. A Philosophical Investigation of Rape: The Making and Unmaking of the Feminine Self. London: Routledge.

Dutton, K. 1995. The Perfectible Body: The Western Ideal of Male Physical Development. New York: Continuum.

Estrich, S. 1987. Real Rape. Cambridge, Massachusetts: Harvard University Press.

Fasiku, G. 2008. "African Philosophy and the method of ordinary language philosophy". Journal of Pan African studies, Vol.2 No.3, pp.100-116.

Fernández, M.L., Y.R. Castro and M.G. Lorenzo. 2004. "Evolution of Hostile Sexism and Benevolent Sexism in a Spanish Sample". Social Indicators Research, Vol.66, pp.197-211.

Foucault, M. 1977. Discipline and Punish: the birth of prison. Sheridan, Alan trans. London: Allen Lane.

Gaidzanwa, R. 1985. Images of Women in Zimbabwean Literature. Harare: The College Press.

Githinji, P. 2008. "Sexism and (mis)representation of women in Sheng". Journal of African Cultural Studies, Vol.20 No.1, pp.15-32.

Glick, P. and S.T. Fiske. 1996. "The ambivalent sexism inventory: differentiating hostile and benevolent sexism". Journal of Personality and Social Psychology, Vol.70, pp.491-512.

Groth, N.A. andH.J. Birnbaum. 2001. Men Who Rape: The Psychological Perspectives. London: Sage Publishers.

Gyekye, K. 1997. Tradition and modernity: Philosophical Reflections on the African Experience. New York: Oxford University Press. 
Haber, H.F. 1996. "Foucault pumped: body politics and the muscled women". Heckman, S.J. ed. Feminist Interpretations of Michel Foucault. University Park, PA: Pennsylvania State University Press, pp.137-156.

Hanson, F.A. 1979. "Does God Have a Body? Truth, Reality and Cultural Relativism". Man, Vol.14 No.3, pp.515-529.

Hirst, P.H. andP. White. 1998. "The Analytic Tradition and Philosophy of Education: An Historical Perspective". Hirst, P.H. and P. White eds. Philosophy of Education: Major Themes in the Analytic Tradition, Vol.1. London: Routledge, pp.1-12.

Hooker, J. 2003. Working across cultures. Stanford: Stanford University Press.

Kim, U. et.al. 2000. "The Challenge of Cross-Cultural Psychology: The Role of Indigenous Psychologies". Journal of Cross-Cultural Psychology, Vol.31 No.1, pp.63-75.

Kittleson, M.J. et. al. 2005. The Truth about Rape. New York: Routledge.

MacCannell, D. andJ.F. MacCannell. 1993. "Violence, Power, and Pleasure: A Revisionist Reading of Foucault from the Victim Perspective". Ramazanoğlu, Caroline ed. Up Against Foucault: Explorations of some Tensions between Foucault and Feminism. London: Routledge, pp.203-238.

Miller, G.A. 2004. Learning the Language of Addiction Counseling. New York: John Wiley and Sons.

Moffett, H. 2006. "These Women, They Force Us to Rape Them: Rape as Narrative of Social Control in Post-Apartheid South Africa". Journal of Southern African Studies, Vol.32 No.1, pp.129-144.

Musarurwa, W. 1988. "Was it really rape? Only the court must decide". The Herald, June 10, 1988, p4.

Oduor, R.M.J. 2009. "Mental impediments to desirable social transformation in contemporary Africa". Thought and Practice: A Journal of the philosophical Association of Kenya, Vol.1 No.1, June 2009, pp.1-29.

Rowland, D. 2004. The Boundaries of her Body: The Troubling History of Women's Rights in America. New York: Sphinx Publishers.

Scully, D. 1994. Understanding Sexual Violence: A Study of Convicted Rapists. London: Routledge.

Shire, C. 1994. "Men Don't go to the Moon: Language, Space and Masculinities in Zimbabwe". Cornwall, A. and N. Lindisfarne eds. Dislocating Masculinity: Comparative Ethnographies. London: Routledge, pp147-158.

Smith, Merril D. 2004. "Introduction". Smith, M.D. ed., Encyclopedia of Rape. London: Greenwood Publishing.

Spivak, G.C. 1988. "Can the Subaltern Speak?" in Nelson, C. and L. Grossberg eds. Marxism and the Interpretation of Culture. Chicago: University of Illinois Press, pp.271-313.

Vest, J.L. 2009. "Perverse and Necessary Dialogues in African Philosophy,". Thought and Practice: A Journal of the Philosophical Association of Kenya, Vol.1 No.2, December 2009, pp.1-23.

Ward, C.A. 1995. Attitudes toward Rape: Feminist and Social Psychological Perspectives. London: Sage Publishers. 